\title{
NEFORMALNO PRIDOBIVANJE ZNANJA TUJEGA JEZIKA
}

Katarina Bizjak

Fakulteta za šport Univerze $v$ Ljubljani

\section{POVZETEK}

Izobraževanje je kompleksna struktura različnih procesov, v katerih se dinamično prepletata tako formalno kot neformalno izobraževanje. Namen raziskave je bil ugotoviti, kakšen vpliv imajo različne oblike neformalnega izobraževanja na uspeh učenja tujega jezika na jezikovnih tečajih. Analiza rezultatov kaže, da so vplivi pomembni in da tečajniki, ki se več neformalno izobražujejo, dosegajo boljše rezultate v primerjavi s tistimi, ki se manj. Raziskava prinaša pomembna dognanja o vplivih neformalnega izobraževanja na uspešnost učenja. Ugotovitve kažejo, da imajo pri učenju tujega jezika različne oblike neformalnega izobraževanje pomemben vpliv na učinkovitost andragoškega cikla, zato ga je treba vanj vključiti v večji meri.

Ključne besede: neformalno izobraževanje, tuji jeziki, andragoški cikel, učna uspešnost

\section{INFORMAL FOREIGN LANGUAGE ACQUISITION - ABSTRACT}

Education is a complex structure, in which formal and informal education are dynamically intertwined. The aim of this research study was to establish how various forms of informal education affect foreign language learning performance on foreign language courses. The analysis of the results shows that the impacts are significant and that the course participants who are more engaged in informal learning do better than those who are less engaged. The study brings significant findings on the effects of informal education on learning success. They show that in various types of informal education in foreign language acquisition the effects of the completed andragogical cycle are significant; therefore; it needs to be included in the process to a greater extent.

Keywords: informal education, foreign languages, andragogical cycle, learning success

\section{UVOD}

Ena izmed ključnih usmeritev 21. stoletja je koncept vseživljenjskega izobraževanja. Izobraževanje je kompleksna struktura različnih procesov, v katerih se dinamično prepletajo različni načini učenja, ki presegajo okvire formalnega izobraževanja. Vzroki za dodatno izobraževanje niso neznani. Dr. Ana Kranjc piše: »Vseživljenjsko izobraževanje, vzgoja in osebnostni razvoj naj bi zvišali stopnjo, na kateri neka oseba lahko deluje v razmerju do svojega okolja.« (Kranjc, 1996: 6) To je zelo transparentno prav pri učenju tujih jezikov, saj tovrstno znanje »odpira vrata $\mathrm{v}$ globalno komunikacijo in je ena od ključnih prednosti posameznika« (Zorko Mencin, 2003: 71), zato se jih učimo vse življenje.

$\mathrm{V}$ preteklosti je bila za pridobitev delovnega mesta pomembna predvsem formalna izobraz- ba, danes ni več tako. »S starimi, ustaljenimi potmi šolanja ni mogoče več zadovoljevati sproti porajajočih se potreb po znanju v poindustrijski družbi.« (Kranjc, 2007) Formalna izobrazba, pridobljena s formalnim izobraževanjem, je še vedno pomembna, a jo je treba stalno dopolnjevati. Danes se zaposluje posamično, v ospredje prihajajo drugačna, specialna znanja posameznika, zato je proces vseživljenjskega izobraževanja ključen za uspešno strokovno rast. Drugačnost in individualizacija pri delu sta posledica individualnega izobraževanja posameznika, ki vsakomur omogoča, da pridobi za svoje delo pomembna znanja. Paradigme neformalnega izobraževanja so tesno povezane s preostalimi temeljnimi pojavi, ki zahtevajo fleksibilno izobraževanje za konkre- 
tne življenjske in delovne situacije posamezne osebe.

Tako danes zaznavamo spremembo $\mathrm{v}$ paradigmah izobraževanja. Prehajamo od šolanja $\mathrm{k}$ vseživljenjskemu izobraževanju. $\mathrm{V}$ novih paradigmah motivacija izpodriva prevladujo-

$\checkmark$ novi paradigmi cilj ni več poklic, temveč kompetenthost in zaposljivost. či pomen sposobnosti, znanja ne prenašamo zgolj naprej na mlajše rodove, temveč vzgajamo in spodbujamo osebnostni razvoj učečih, individualno izobraževanje pa postaja vedno pomembnejše, medtem ko skupinsko izgublja pomen. $\mathrm{V}$ novi paradigmi cilj ni več poklic, temveč kompetentnost in zaposljivost, zato se ne omejujemo le na nacionalne šolske sisteme, temveč izobraževanje postaja globalno. V tem konceptu zgolj formalno izobraževanje ne zadostuje več, zato v ospredje prihaja neformalno (Kranjc, 2007). Za delodajalce danes ni več pomembno, kako je oseba pridobila svoje znanje, temveč kaj oseba zna (Beck, 1996; Kranjc, 2007). Zato je treba raziskovanje usmeriti tudi v preostale oblike pridobivanja znanja odraslih in jih spodbujati.

\section{FORMALNO IN NEFORMALNO IZOBRAŽEVANJE}

Vseživljenjsko izobraževanje je vseobsegajoča učna aktivnost, bodisi formalna (ang. formal) bodisi neformalna (ang. non-formal). Formalno izobraževanje je hierarhično strukturirano izobraževanje, ki zajema vse od osnovnih šol do fakultet in vodi do uradno priznanih diplom in kvalifikacij (Devjak, T., 2007: 121; English, 2005; Colleta, N. J., 1996; Jarvis, P., 1990). Običajno ima hierarhično strukturo $s$ kronološkim zaporedjem letnikov in stopenj, jasno definirane vstopne pogoje in formalni vpisni postopek, opredeljene metode dela in evalvacijo. Odvija se v okviru kurikula izobraževalne ustanove (Pevec Grm, 2006; English, L. M, 2005; Gornik, 2005). Izobraževanje spreminja človekov položaj v družbi, kar pomeni, da z različnih vidikov spreminja njegov način življenja, izboljšuje njegove materialne možnosti, povečuje ugled, razgledanost in kakovost življenja.

Neformalno izobraževanje se odvija zunaj glavnih sistemov izobraževanja in usposabljanja in ni nujno, da vodi do formaliziranih certifikatov. Lahko poteka na delovnem mestu, skozi družbeno interakcijo, z informacijami, ki nam jih posredujejo mediji, z osebnimi izkušnjami, branjem, z aktivnostmi organizacij in skupin civilne družbe (kot so mladinske organizacije, sindikati, politične stranke) (Devjak, T., 2007: 121-122; English, L. M., 2005; Bjornavold, 2000: 11). Lahko se zagotavlja tudi z organizacijami in službami, ki so bile ustanovljene kot komplementarne formalnemu sistemu izobraževanja (na primer ure umetnosti, glasbe, športa, inštrukcije kot priprava na izpit), lahko pa se dopolni s priložnostnim izobraževanjem (ang. informal education), ki je naravni spremljevalec vsakdanjega življenja, za katerega ni nujno, da je namerno, zato tudi ni nujno, da ga posamezniki prepoznajo kot tisto vrsto učenja, ki povečuje njihovo znanje in spretnosti (Devjak, T., 2007: 121-122). Unescova terminologija opredeljuje neformalno izobraževanje kot »proces, ki poteka vse življenje, pri katerem vsak oblikuje stališča, pridobiva vrednote, spretnosti in znanje iz vsakdanjih izkušenj, izobraževalnih vplivov v svojem okolju, družini, soseski, knjižnici ...«(Rogers, A., 2005). Bjornavold (2000: 11) pa poudarja, da je neformalno izobraževanje lahko tudi strukturiran in načrtovan proces, ki poteka zunaj institucionalnega konteksta, pridobljena znanja pa se v nekaterih primerih tudi preverjajo in potrjujejo $\mathrm{z}$ javno veljavnimi potrdili (na primer potrdilo o aktivnem znanju tujega jezika) (Gornik, 2005: 4).

Tovrstno spontano izobraževanje dr. Ana Kranjc (2000: 48) opredeljuje kot »sprotno, osebno zadovoljevanje posameznikovih potreb po znanju $\mathrm{v}$ neposrednih okoliščinah in življenjskih razmerah «. Ljudje iščemo znanje na različne načine, najuspešnejši pa so tisti, ki izvirajo neposredno iz našega okolja in naših 
interesov. O stvareh, ki nas zanimajo, se lahko poučimo pri sorodnikih, prijateljih in znancih. K njim lahko pristopimo direktno, o problematiki se lahko pogovarjamo po telefonu ali pa si dopisujemo. Informacije lahko poiščemo v knjigah, priročnikih, na svetovnem spletu, v revijah, časopisih ali drugih avdio-vizualnih medijih. Prav tako lahko odgovore poiščemo na kraju, kjer stvar poteka ali se izvaja. Oblikujejo se lahko tudi skupine, ki si pri takem učenju pomagajo. Lahko so vezane na določen kraj ali situacijo in oblikujejo svoje vzorce obnašanj. Dr. Ana Krajnc (2000: 48) tako piše, »da se v določenem kraju izluščijo najuspešnejši vzorci in strategije spontanega izobraževanja«. Ti se nato prenašajo naprej.

Zanimalo nas je, koliko imajo različne oblike neformalnega izobraževanje vpliv na uspešnost učenja. Slednje bi lahko imele pri učenju tujega jezika, kjer je potrebno postopno in sistematično razvijanje sposobnosti slušnega razumevanja, branja, pisnega in ustnega izražanja (Zorko Mencin, 2003), pomembno vlogo. Poleg tega moramo za uspešno učenje pri načrtovanju dela upoštevati tudi zakonitosti andragoškega cikla. Poznavanje vplivov lahko namreč vključimo v posamezne dele andragoškega cikla in jih še izboljšamo. Pri izobraževanju odraslih je pomembno, da ne izpustimo katere od njegovih faz. Po Rečniku (2004: 124) si faze sledijo tako: ugotavljanje potreb (interesi, sedanje in predvi- dene potrebe, želje posameznikov), programiranje (izbor vsebin glede na učne cilje in skupino), priprava (osnovni izvedbeni model, trajanje, intenzivnost, učne metode, sredstva, sklopi, moduli, prostor in oprema), izvedba (avtonomno učenje, koordinacija, usmerjanje, svetovanje andragoga), evalvacija oziroma vrednotenje doseženih rezultatov (začetna, sprotna, končna evalvacija). Različne oblike neformalnega izobraževanja tako sodijo $\mathrm{v}$ avtonomno učenje, katerega količina ni zanemarljiva. Zanimalo pa nas je, ali se ti učinki kažejo tudi na testu znanja. V svoji raziskavi je Tough (1972, v Kranjc, 2007) že ugotovil, da je razmerje med formalnim in neformalnim izobraževanjem posameznikov $\mathrm{v}$ učnih projektih, kot je učenje tujega jezika, 80 proti 20 odstotkom v prid neformalnega izobraževanja. Učenje jezika se $\mathrm{v}$ odrasli dobi pogosto začenja od začetka, zato je zelo zanimivo za raziskovanje vplivov na ta proces.

\section{TEČAJI ALI ŠOLE SO LE OSNOVA NEFORMALNEGA IZOBRAŽEVANJA}

Temeljna naloga učinkovitega izobraževanja na področju tujih jezikov je, da udeležence čim hitreje usposobimo za samostojno komunikacijo $\mathrm{v}$ tujem jeziku. Poznavanje vplivov na intenzivnost učenja je tako izredno pomembno za kakovostno izobraževanje. »Vedno več se učimo na 'kraju sa-

Muršak (2006) v svojem članku navaja jasno razmejitev med formalnim in neformalnim izobraževanjem po Hagerju iz leta 2001. Neformalno izobraževanje je nepredvidljivo in nima določenih standardov in glede na to tudi ni mogoče meriti njegovih rezultatov. Vsako formalno izobraževanje pa mora imeti jasne cilje vsaj na globalnem nivoju. Razlika je tudi v nenavzočnosti učitelja, trenerja, mentorja, ki organizira ali vsaj posredno skrbi za organizirano delovno okolje. Rezultati neformalnega učenja ostajajo večinoma nevalorizirani. Čeprav posameznik razvije določene kompetence in tako bolje opravlja delo ali je njegovo znanje tako globlje, širše, ostaja to znanje v obliki, ki je ni mogoče formalno izraziti. Neformalno pridobljenega znanja ni mogoče sistematično, v organizirani obliki, prenašati naprej. Formalno izobraževanje običajno ponuja neko teoretsko podlago, na kateri se nato gradi aplikativno znanje, v nasprotju z neformalnim, ki ne obstaja neodvisno od konkretne situacije. Pri formalnem izobraževanju znanje pogosto ostaja na ravni teoretsko nepovezanega praktičnega vedenja o nečem, pri neformalnem pa redko pride do konceptualizacije znanja in razumevanja teoretske podlage. Čeprav je formalno izobraževanje jasno strukturirano in kontrolirano, pa na igriščih in hodnikih izobraževalnih ustanov v času formalnega izobraževanja poteka tudi veliko neformalnega, nenačrtovanega izobraževanja (English, 2005). 
mem' in vedno manj je ločenega učenja $\mathrm{v}$ posebej rezerviranem času.«(Kranjc, 2007: 15)

Uspešnost dela na tečajih se spremlja z internimi in eksternimi testi znanja, ob tem pa se moramo zavedati, da so rezultati lahko tudi posledica Naloga izobraževanja na področju tujih jezikov je, da zna udeleženec čim prej govoriti tuji jezik.

drugih dejavnikov iz okolja tečajnikov in oblik neformalnega izobraževanja. Da lahko poskusimo vplivati tudi na te dejavnike, moramo najprej osvetliti, na katera področja posegajo. Ljudje se jih velikokrat ne zavedamo, pridobljeno znanje pa je komplementarno povezano.

Glavni namen raziskave je bil ugotoviti, koliko se udeleženci poleg jezikovnega tečaja na jezikovni šoli izobražujejo tudi z drugimi oblikami neformalnega izobraževanja. Kombinacija jezikovnega tečaja z oblikami neformalnega izobraževanja je izredno koherentna predvsem na področju motivacije, ki je ena od novih paradigem izobraževanja. Čeprav se jezika želimo naučiti sami, je to v neorganizirani obliki izredno težko. Poleg izobraževanja na tečaju pa lahko znanje sami zagotovo dvignemo na višjo raven s komplementarnimi oblikami učenja. Ugotavljali smo, kakšni so ti medsebojni vplivi.

Iskali smo različne možnosti za izboljšanje našega delovanja na neformalni ravni. Izbrali smo skupino tečajnikov jezikovnih tečajev, ki imajo skupen interes za učenje jezika, a se razlikujejo po starosti, izobrazbi in življenjskem slogu. $\mathrm{Na}$ podlagi ankete smo ugotavljali, ali se na kakšen način še dodatno neformalno izobražujejo in kakšen vpliv ima to na učno uspešnost. Pri izobraževanju pa ne moremo govoriti o enostranskem izobraževanju. Vrste izobraževanja se pogosto prepletajo. Velikokrat se dogaja, da ena oblika izobraževanja posamezniku ni zadostna, mu »... ne pomeni veliko, če je ne dopolni še z drugimi oblikami individualnega izobraževanja«. (Kranjc, 2000: 48) Z njimi posameznik pridobljeno znanje osmisli, ga uporabi in tako to postane trajnejše in kakovostnejše.

\section{RAZISKAVA O NEFORMALNEM IZOBRAŽEVANJU NA PODROČJU TUJEGA JEZIKA}

\section{Udeleženci}

$\mathrm{V}$ raziskavi je sodelovalo 67 odraslih $(\mathrm{n}=27$ žensk, $n=40$ moških), ki so se $v$ šolskem letu 2007/08 udeleževali jezikovnih tečajev na eni od jezikovnih šol v Kranju. Njihova starost je bila od 20 do 64 let. Poleg delitve na skupine po jezikih so bili tečajniki na začetku andragoškega cikla (cikel je sovpadal s šolskim letom) razdeljeni v homogene skupine po znanju, ki smo ga ugotavljali z razvrstitvenimi testi znanja. Večina anketirancev (59 odstotkov) se uvršča v skupino odraslih od 30 do 49 let. Torej v skupino, ki se, kot pravi Knowles (1972), izobražuje zato, da bi zvišali stopnjo, na kateri delujejo v razmerju do svojega okolja. Po izobrazbeni strukturi so anketiranci precej razpršeni. Prevladujejo tečajniki z univerzitetno (31 odstotkov) in gimnazijsko izobrazbo (31 odstotkov), sledi skupina z višjo izobrazbo s 16 odstotki. Pri starostni skupini od 20 do 29 let je izobrazba odvisna od starosti, člani te skupine se nadalje še izobražujejo na fakulteti, druge starostne skupine pa so enakomerno razporejene med preostale stopnje izobrazbe. Nekoliko več kot 33 odstotkov jih je z univerzitetno izobrazbo.

Ker je to zelo specifična skupina tečajnikov na jezikovnih tečajih, ni nenavadno, da jih jeziki delno (37 odstotkov) in zelo zanimajo (63 odstotkov). Veliko anketirancev (40 odstotkov) se je doslej učilo treh ali več tujih jezikov, le za 33 odstotkov anketirancev je to prvi tuji jezik, ki se ga učijo. Tudi izbor tujih jezikov, ki so se jih posamezniki že učili, je izredno velik. Po pogostosti učenja so navedli naslednje jezike: angleščina (najpogosteje), nemščina, španščina, francoščina, italijanščina, ruščina in hrvaščina.

\section{Pripomočki}

Osnovne podatke o tečajnikih, podatke o jeziku, ki se ga učijo v jezikovni šoli, podatke o drugih 
Preglednica 1: Oblike neformalnega izobraževanja

\begin{tabular}{|l|l|}
\hline Televizija & spremljanje televizijskih oddaj in filmov v tujem jeziku \\
\hline Radio & spremljanje radijskih oddaj v tujem jeziku \\
\hline Računalnik & poslušanje in prepevanje glasbe v tujem jeziku \\
\hline Glasba & $\begin{array}{l}\text { učenje jezika s pomočjo računalnika: deskanje po spletu in branje člankov v tujem jeziku } \\
\text { na spletu, učenje s pomočjo CD/DVD-jev ali avdio kaset }\end{array}$ \\
\hline Branje & branje knjig in revij v tujem jeziku \\
\hline Prijatelji & komunikacija s sorodniki in prijatelji po telefonu in pošti \\
\hline Potovanje & izobraževanja v tujini, počitnice v tujini, poslovni stiki s tujino \\
\hline
\end{tabular}

tujih jezikih, ki jih znajo, podatke o prostočasnih aktivnostih, podatke o neformalnem izobraževanju in podatke o zanimanju za tuje jezike smo zbirali $\mathrm{z}$ anketnim vprašalnikom.

Pri podatkih o neformalnem izobraževanju so tečajniki na petstopenjski lestvici $(1-$ nikoli, 2 - redko, 3 - občasno, 4 - pogosto, 5 - zelo pogosto) odgovarjali na sedem sklopov trditev (Preglednica 1). Vsak od sklopov je zajemal tri do pet trditev.

Podatke o učni uspešnosti smo pridobili na podlagi internih testov znanja, ki so bili prilagojeni posamezni skupini tečajnikov. Testi znanja so bili ovrednoteni po skupinah, a na enotni lestvici. Na testu je bilo možno zbrati 50 točk, za uspešno oceno so morali doseči vsaj 30 točk. Ker so bili tečajniki na začetku andragoškega cikla razvrščeni v homogene skupine na podlagi razvrstitvenega testa znanja, smo lahko s polletnimi testi ugotavljali, kako različno so napredovali v znanju. Tečajniki se ob koncu študijskega leta preverijo na eksternih testih znanja na nacionalni ravni, s katerimi lahko pridobijo javno priznane listine. Teh rezultatov nismo dobili.

\section{Potek raziskave}

Anonimno anketiranje smo izvedli januarja 2008. Anketiranje so vodile predavateljice jezikovne šole na koncu ure jezikovnega tečaja, tako da pedagoški proces ni bil oviran. Motivacija anketirancev je bila velika, saj so predavateljice poročale, da so vprašalnike vsi rešili brez težav in v celoti. Zanimivo je, da so se nekateri po reševanju vprašalnika zavedeli, da se z jezikom poleg jezikovnega tečaja zelo veliko ukvarjajo in se je o tej temi razvila razprava. Predavateljice so poročale tudi o tem, da so tečajniki začeli bolj posegati po literaturi $\mathrm{v}$ tujem jeziku. Interni test znanja je bil opravljen ob zaključku prvega od dveh semestrov $\mathrm{v}$ andragoškem ciklu. $\mathrm{Z}$ rezultati testov znanja smo tečajnike povezali s pomočjo kode, s katero so ti označili anketo in rezultat testa.

\section{Metode obdelave podatkov}

S statističnim program SPSS 18.0 za Windows smo opravili naslednje statistične analize: osnovne deskriptivne analize, korelacijske analize in analizo variance (ANNOVA). Stopnja statistične značilnosti je bila določena $\mathrm{s} p \leq$ 0,05. NEFORMALNEGA IZOBRAŽEVANJA Rezultati raziskave so pokazali, da se poleg obiskovanja tečajev tujih jezikov vsi anketiranci neformalno izobražujejo (Grafični prikaz 1).

\section{PREPLETANJE FORMALNEGA IN NEFORMALNEGA IZOBRAŽEVA- NJA PRI UČENJU TUJEGA JEZIKA}

Primarna motivacija učencev vpliva na nadaljevanje učenja tudi po neformalnih poteh. V osebnem življenju najdejo priložnosti za neformalno učenje tujega jezika. Sodobna tehnologija in razširjenost medijev to omogočata na vsakem koraku.

Rezultati potrjujejo, da je televizija v današnjem času vodilni medij, saj kar 90 odstotkov anketirancev (65 odstotkov občasno) spremlja televizijske postaje v tujem jeziku. Glede poslušanja 


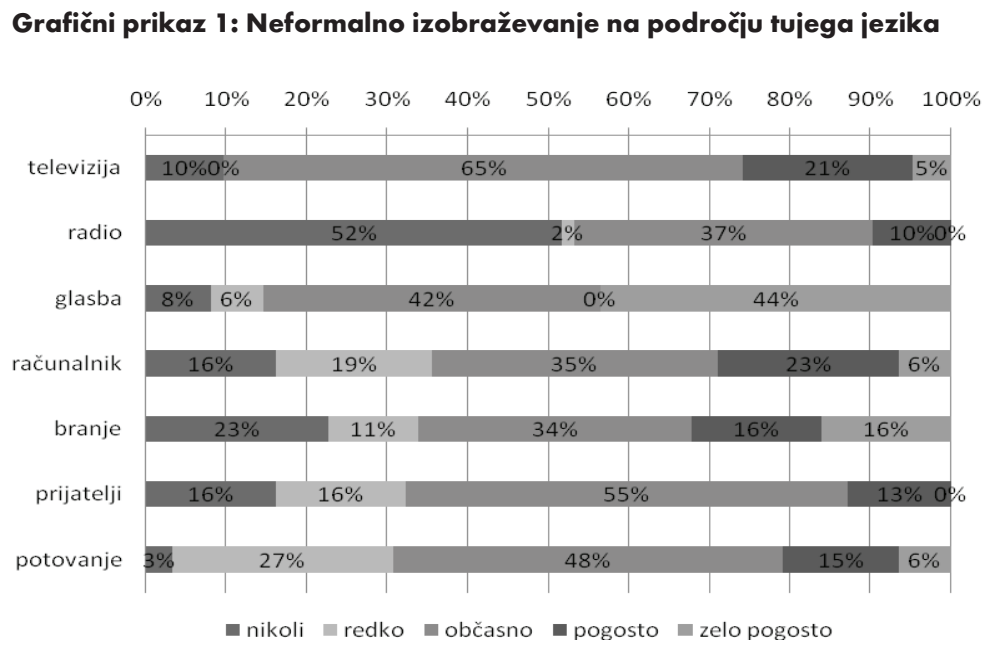

radia pa je 52 odstotkov anketirancev odgovorilo, da ne spremlja oddaj v tujem jeziku. Kljub temu iz tega ne smemo sklepati, da ne poslušajo radia. V Sloveniji namreč na radijskih postajah le redko slišimo oddaje $\mathrm{v}$ tujem jeziku, medtem ko je to na televizijskih postaja ustaljena praksa. $\mathrm{Na}$ to, da spremljajo radijske postaje, nakazuje tudi podatek, da le 14 odstotkov (osem odstotkov nikoli, šest odstotkov redko) anketirancev ne posluša tujejezične glasbe,

\section{Televizija je vodilni} medij za neformalno učenje tujega jezika. ki je na radijskih programih izredno pogosta, zagotovo pa jo poslušajo tudi prek drugih medijev. Vzroki za to so lahko različni. Slika našega povprečnega anketiranca kaže, da je to izredno zaposlen človek $\mathrm{z}$ družino, ki se $v$ prostem času ukvarja $z$ jeziki in športom ter tako le težko najde veliko časa za gledanje televizije, medtem ko lahko radio posluša tako v avtomobilu kot na delovnem mestu.

Pomembno je tudi učenje tujega jezika s pomočjo CD/DVD-jev ali avdio kaset. Da se izobražujejo na ta način, je potrdilo 65 odstotkov anketirancev (od tega 35 odstotkov občasno, preostali pa pogosto ali zelo pogosto). Tovrstno izobraževanje je zagotovo izredno priročno, saj ne zahteva določenega termina in po začetni naložbi ni povezano z drugimi (časovnimi, prostorskimi, finančnimi) obremenitvami. Pri takem izobraževanju pa vedno ostajajo slabe strani. Ena izmed teh je zagotovo pomanjkanje konsistentnosti, veliko ljudi namreč ni sposobno samoiniciativno vztrajati pri učenju doma. Druga negativna stran tega učenja je, da posameznik ne dobi povratne informacije o svojem znanju in tako lahko prihaja do večjih ali manjših anomalij $\mathrm{v}$ znanju. $\mathrm{V}$ povezavi $\mathrm{s}$ tečajem $\mathrm{v}$ jezikovni šoli pa je to lahko način za hitrejši napredek.

Najpogostejši način izpopolnjevanja znanja tujega jezika je uporaba jezika v socialnih situacijah, kot so obiski prijateljev ali sorodnikov iz tujine, kar 68 odstotkov (55 odstotkov občasno in 13 odstotkov pogosto) anketirancev v tujem jeziku komunicira s prijatelji ali sorodniki. Komunikacija v tujem jeziku zagotovo pomeni močno motivacijo za učenje tujega jezika, pogovor s prijatelji ali sorodniki je tako eden najpreprostejših načinov učenja tujega jezika. Izredno velik delež anketirancev, 70 odstotkov (48 odstotkov občasno, 21 odstotkov pa pogosto ali zelo pogosto), potuje $\mathrm{v}$ tujino. $\mathrm{V}$ to kategorijo smo uvrstili študentske izmenjave, seminarje, prakso $\mathrm{v}$ tujini, počitnice $\mathrm{v}$ tujini in sodelovanje s poslovnimi partnerji v tujini. Tako 42 odstotkov anketirancev (15 odstotkov zelo pogosto in 21 odstotkov pogosto) sodeluje s poslovnimi partnerji v tujini. $Z$ globalizacijo in vključenjem v Evropsko unijo se je trg dela in delovne sile zelo razširil. Tako danes potekajo izobraževanja in sodelovanja za vse nivoje bolj globalno. $\mathrm{V}$ tujini ne organizirajo le izobraževanj za vodilne delavce, temveč tudi za preostale. Prav tako je veliko sodelovanja med poslovnimi partnerji na več nivojih. Izmenjava znanj in izkušenj prek meja je izredno pomembna za uspeh posameznika in podjetij. Za tako izobraževanje je zagotovo pomembno tudi solidno znanje tujega jezika, prav tako pa je na teh izobraževanjih znanje jezika mogoče tudi izpopolniti.

Tudi branje ima med našimi anketiranci pomembno mesto. Dvaintrideset odstotkov (16 odstotkov pogosto in 16 odstotkov zelo pogosto) jih bere $\mathrm{v}$ tujem jeziku, najpogosteje članke $\mathrm{v}$ 
tujem jeziku na svetovnem spletu. Ta podatek kaže, da je kultura branja med našimi anketiranci na solidni ravni. Branje je zelo dober način učenja, omogoča nam počasno premlevanje besed, ki jih ne poznamo, ter spremljanje slovnice $\mathrm{v}$ prijetnem, neprisiljenem ozračju. Branje s slovarjem pa pripomore $\mathrm{k}$ kakovostnejšemu razumevanju besedila.

Zanimivi so tudi prvi stiki s tujim jezikom. Najpogosteje so se $\mathrm{z}$ njim prvič seznanili $\mathrm{v}$ šoli, osnovni ali srednji, na drugem mestu po pogostosti pa so potovanja. Na potovanjih so ljudje mnogo bolj odprti za zunanje vplive kot običajno in so tako tudi bolj dojemljivi. Pozitivno izkušnjo s potovanja lahko ohranjajo $s$ slikami in posnetki, z ohranjanjem stikov s prijatelji in/ali pa s poglabljanjem znanja jezika. Potovanje in stik s tujimi jezikom sta lahko že tudi sama po sebi motivacija za učenje. Slednje je v tej skupini anketirancev prevladujoče.

\section{ZNANJE TEČAJNIKOV}

Vsi tečajniki, vključeni v raziskavo, so se udeležili internega testa znanja, trije izmed njih pri testu niso zbrali dovolj točk za uspešno opravljen preizkus.

Test znanja je pokazal, da so tečajniki pridobili različno količino znanja. Ocene se po spolu statistično značilno ne razlikujejo. Tečajniki, ki jih tuji jeziki bolj zanimajo (Grafični prikaz 3), pa dosegajo boljše rezultate v primerjavi $\mathrm{z}$ drugimi $\left(r_{s}=0,462\right)$.

Tudi glede na starost se tečajniki različno neformalno izobražujejo, kljub temu pa na testu znanja ne dosegajo statistično značilno različnih rezultatov. Starejši tečajniki predvsem statistično značilno manj berejo v tujem jeziku $\left(r_{s}=-0,581\right)$, potujejo $\mathrm{v}$ tujino $\left(\mathrm{r}_{\mathrm{s}}=-0,466\right)$, gledajo televizijske programe $\mathrm{v}$ tujem jeziku $\left(\mathrm{r}_{\mathrm{s}}=0,454\right)$ ter poslušajo in pojejo glasbo v tujem jeziku $\left(r_{s}=-0,373\right)$.

Analiza variance je pokazala, da so razlike med uspešnostjo na testu znanja in številom jezikov, ki so se jih tečajnik že učili, statistično pomembne $(\mathrm{p}=0,018)$. Tečajniki $\mathrm{z}$ več
Grafični prikaz 2: Razpršenost ocen

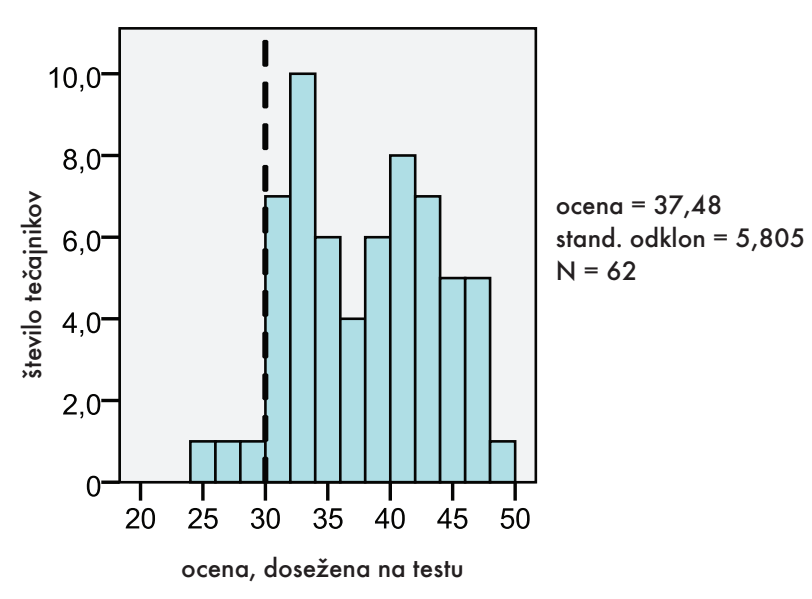

Grafični prikaz 3: Interes za tuji jezik

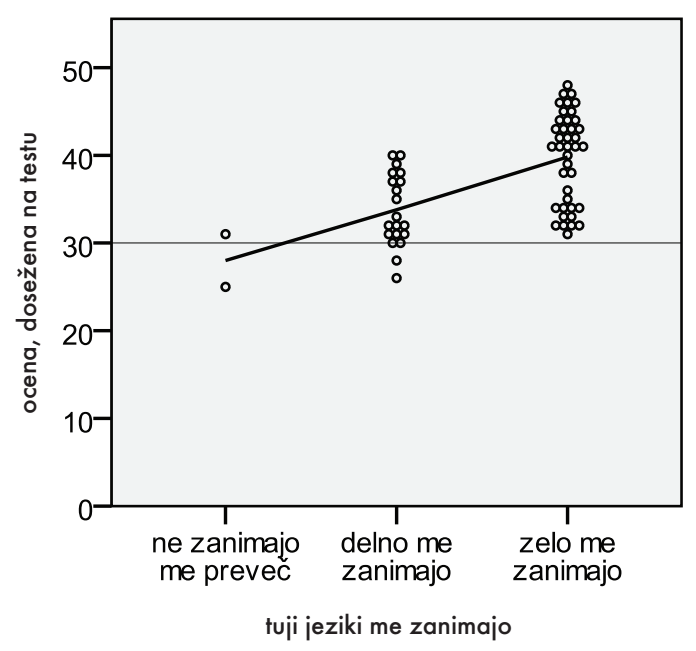

izkušnjami pri učenju tujih jezikov (Grafični prikaz 4) na polletnih testih znanja dosegajo boljše rezultate. Kljub temu pa ne moremo reči, da so ti rezultati enaki tudi na koncu andragoškega cikla. Tečajniki, ki so se učili že več tujih jezikov, so na testu znanja statistično značilno $\left(r_{s}=0,381\right)$ uspešnejši kot tečajniki, za katere je to prvi tuji jezik. S tem ko se posameznik uči več jezikov, gre večkrat skozi postopek pomnje-

\section{Zanimanje tečaj- nika za tuji jezik prinese boljse učne rezultate.}


Spermanov korelacijski koeficient rangov nakazuje pozitivno korelacijo med izobrazbo in neformalnim izobraževanjem $(\mathrm{rs}=0,359)$. Tečajniki z višjo izobrazbo statistično značilno več berejo $(\mathrm{rs}=0,396)$ in se pogovarjajo $\mathrm{v}$ tujem jeziku (rs $=0,470)$. Prav tako pogosteje potujejo v tujino, kjer imajo nato stike $\mathrm{v}$ tujem jeziku ( $\mathrm{rs}=0,540)$. Prav te tri spremenljivke so pogosto povezane $\mathrm{z}$ delovnimi mesti, na katerih so zaposleni tečajniki z višjo izobrazbo. Z novopridobljenimi znanji so pogosto povezani tudi napredovanja in dvig plače, pa tudi, če učinek ni takojšen, je močna motivacija že povečana možnost za te spremembe (Muller, 1965: 50). Preostale spremljane oblike neformalnega izobraževanja z izobrazbo niso statistično značilno povezane.

Grafični prikaz 4: Uspešnost na testu znanja v povezavi s številom jezikov, ki so se jih tečajniki že učili

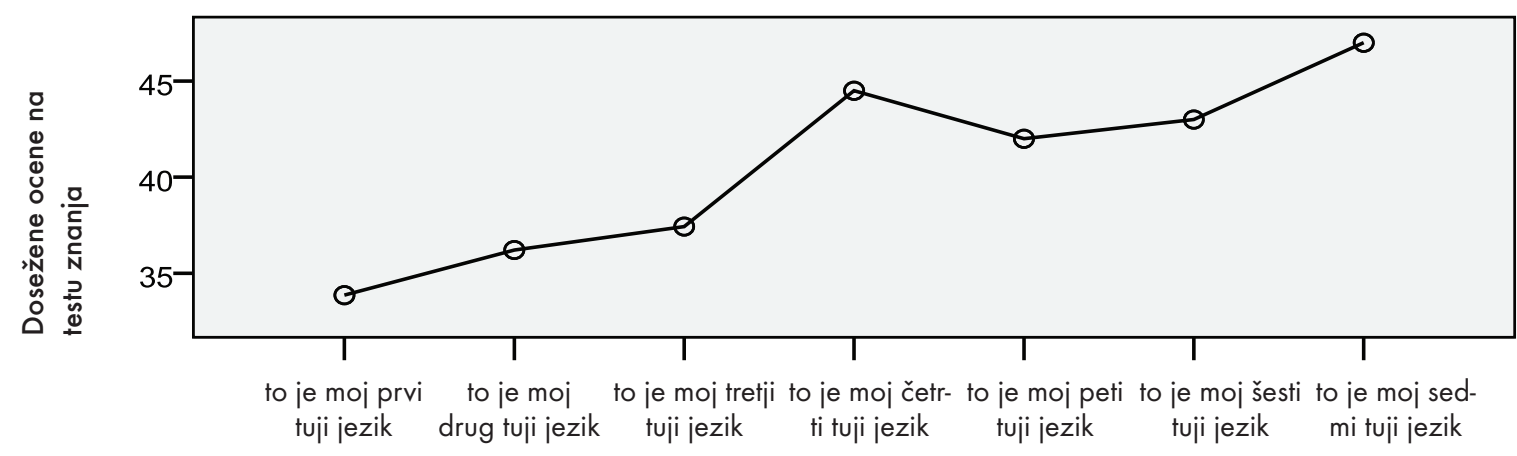

število jezikov, ki so se jih tečajniki učili do sedaj

Grafični prikaz 5: Količina neformalnega izobraževanja v povezavi z uspešnostjo na testu znanja

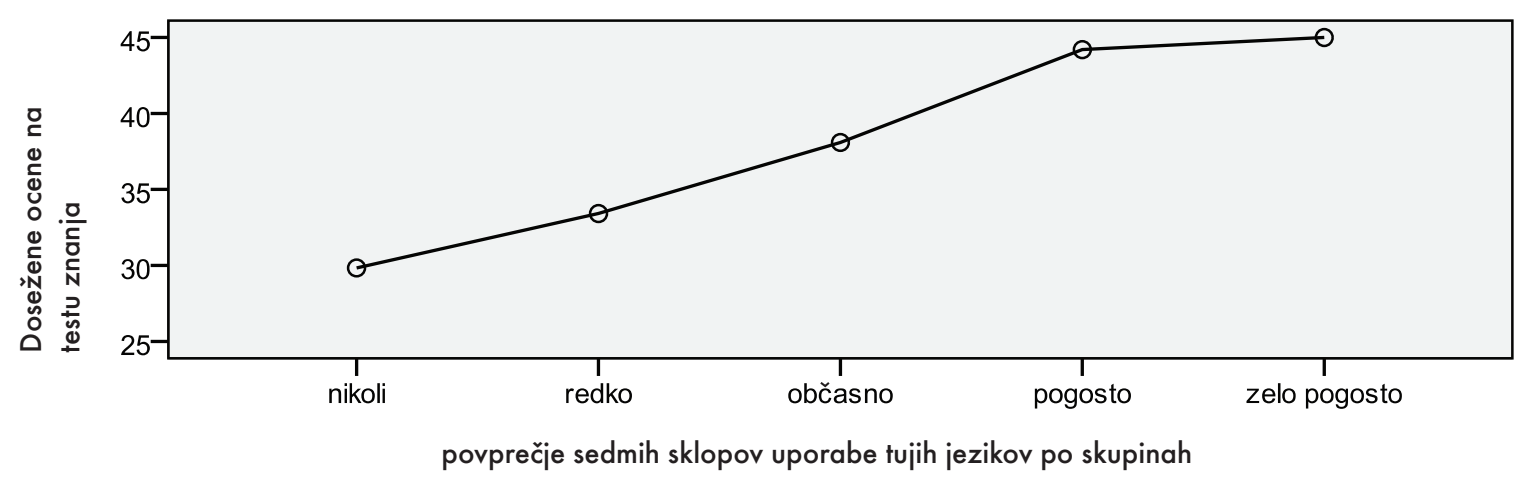

nja besedišča in razumevanja slovnice in tako razvija kompetenco učenje učenja, ki mu lahko močno pomaga pri učenju novega jezika. Prav tako imajo ti odrasli veliko izkušenj, ki s katerimi lahko primerjajo na novo pridobljeno znanje in si ga tako laže zapomnijo (Miller, 1965: 44). Tem tečajnikom se je verjetno laže učiti in so pri tem bolj učinkoviti ter se znajo tudi bolje pripraviti na preverjanje znanja.

\section{VEČ NEFORMALNEGA IZOBRAŽEVANJA, BOLJŠI REZULTATI}

Med neformalnim izobraževanjem in oceno na testu znanja obstaja močna povezava (Grafični prikaz 5). Tečajniki, ki se pogosteje neformalno izobražujejo, so na testih znanja statistično značilno uspešnejši $\left(r_{s}=0,711\right)$. Analiza 
variance kaže, da tečajniki, ki se dodatno veliko neformalno izobražujejo, dosegajo boljše rezultate od tistih, ki se dodatno neformalno ne izobražujejo $(\mathrm{p}<0,000)$.

Med posameznimi sklopi in uspehom na testu znanja obstajajo srednje velike povezave $\left(0,410 \leq r_{s} \geq 0,697\right)$. Najmočnejša povezava $\mathrm{z}$ uspešnostjo je, da tečajniki komunicirajo $\mathrm{v}$ tujem jeziku zunaj jezikovne šole $\left(r_{s}=0,697\right)$.

Preglednica 2: Vrsta neformalnega izobraževanja $\checkmark$ povezavi z uspehom na testu znanja

\begin{tabular}{|l|l|l|}
\cline { 2 - 3 } \multicolumn{1}{c|}{} & \multicolumn{2}{|l|}{ Ocena, dosežena na zaključnem testu } \\
\cline { 2 - 3 } \cline { 2 - 3 } & $\begin{array}{l}\text { Korelaciiski } \\
\text { koeficient } \\
\text { (Spearmanov koef.) }\end{array}$ & $\begin{array}{l}\text { Stat. pom. } \\
\text { (dvostranska) }\end{array}$ \\
\hline Televizija &, $410^{* *}$ &, 001 \\
\hline Radio &, $408^{* *}$ &, 001 \\
\hline Glasba &,$- 641^{* *}$ &, 000 \\
\hline Računalnik &, $576^{* *}$ &, 000 \\
\hline Branje &, $472^{* *}$ &, 000 \\
\hline Prijatelij &, $697^{* *}$ &, 000 \\
\hline Potovanja &, $491^{* *}$ &, 000 \\
\hline
\end{tabular}

** Korelacija je značilna na ravni 0.01 (dvostranska).

\section{OSNOVNE UGOTOVITVE RAZISKAVE}

Odrasli, ki se udeležujejo jezikovnih tečajev, se dodatno veliko neformalno izobražujejo: spremljajo tujejezične televizijske in radijske programe, poslušajo in prepevajo tujejezično glasbo, tuji jezik uporabljajo na računalniku, berejo in komunicirajo v tujem jeziku ter potujejo v tujino. Različne oblike neformalnega iz- obraževanja in njihova količina imajo različno pomembno povezavo $\mathrm{z}$ uspešnostjo pridobivanja znanja. Pogosteje kot tečajniki znanje sočasno prenašajo v prakso, hitreje napredujejo. Pri tem so najuspešnejši tisti, ki jezik uporabljajo v socialnih situacijah, ko komunicirajo v tujem jeziku ali ko se odpravijo v okolja, kjer je tuji jezik stalno v uporabi.

Sodobni mediji so omogočili veliko enostavnejši dostop do informacij. Učenje s pomočjo avdio-vizualnih nosilcev informacij in svetovnega spleta ni več rezervirano za posamezne strokovnjake. Poleg tega, da je postala njihova uporaba mnogo enostavnejša, se je povečalo tudi znanje njihove uporabe, tako da jih lahko uporablja skoraj kdorkoli, vključno z izredno velikim deležem anketirancev, ki tako pridobijo več znanja v primerjavi s tistimi, ki teh možnosti ne izkoriščajo. Te medij statistično značilno manj še vedno uporabljajo starejši odrasli.

Izredno močna motivacija za izobraževanje je tudi potreba po znanju, ki se pojavi na posameznih delovnih mestih. S povečanjem mednarodnega sodelovanja po vstopu v Evropsko unijo in na pragu predsedovanja Uniji je znanje jezika še toliko pomembnejše. Znanje $v$ tem primeru pripomore tudi $\mathrm{k}$ poslovni uspešnosti. Kot pri preostalih socialnih stikih postane tudi pri poslovnih kontaktih znanje jezika eno od sredstev, ki omogoča dvig komunikacije na višjo raven. S samo uporabo, recimo pripravami pred poslovnimi sestanki, pisanjem poročil in podobno, pa se dviguje tudi raven znanja jezika. Tečajniki z višjo izobrazbo so na teh področjih aktivnejši. V pridobljenem znanju

Znotraj posameznih sklopov so posebno zanimive naslednje ugotovitve. Tečajniki, ki pogosto gledajo tuje filme brez podnapisov, so pomembno uspešnejši na testih znanja ( $r s=0,620)$, medtem ko tečajniki, ki gledajo filme s podnapisi, podobno visokih rezultatov ne dosegajo $(\mathrm{rs}=0,134)$. Tečajniki, ki se pogovarjajo v tujem jeziku, obiskujejo prijatelje, ki so tujci, ali sprejemajo na obisk prijatelje, ki so tujci, dosegajo visoke rezultate na testu znanja ( $p>0,600)$, medtem ko tečajniki, ki le preživljajo počitnice v tujini, statistično značilno ne dosegajo boljših rezultatov ( $\mathrm{rs}=0,278$ ). Prve tri navedbe nakazujejo na aktivno interakcijo tečajnikov s tujci, kar zahteva uporabo jezika, medtem ko preživljanje počitnic v tujini s tem ni nujno povezano. Na počitnice se namreč odpravljamo s prijatelji ali družino, tako tudi komunikacija večino časa poteka v maternem jeziku, kar ne pripomore k izboljšanju znanja tujega jezika. 
in to skupino se tako kaže močna povezava. Medtem ko na splošno tečajniki z višjo izobrazbo niso uspešnejši od tistih z nižjo, pa se tisti $\mathrm{z}$ višjo izobrazbo $\mathrm{v}$ nekaterih oblikah neformalnega izobraževanja, kot navedeno $\mathrm{v}$ prejšnjem odstavku, več izobražujejo. Druge razlike smo ugotovili predvsem pri obsegu branja, pogovarjanja in komuniciranja $\mathrm{v}$ tujem jeziku. Tudi po starosti se pojavljajo pomembne razlike, ki jih je treba upoštevati pri spodbujanju odraslih k neformalnemu izobraževanju. Starejši odrasli imajo tako večje težave s potovanji $\mathrm{v}$ tujino, poslušanjem in prepevanjem tujejezične glasbe in branjem $\mathrm{v}$ tujem jeziku.

$\mathrm{Na}$ hitrost učenja imajo različne oblike neformalnega izobraževanja pomemben vpliv. Odrasli, ki se pogosteje neformalno izobražujejo, dosegajo boljše rezultate $\mathrm{v}$ znanju $\mathrm{v}$ primerjavi s tistimi, ki se izobražujejo zgolj na jezikovnem tečaju. Uporaba znanja $v$ osebni praksi udeležencem prinaša več možnosti za utrjevanje znanja, s tem pa pospešuje procese pomnjenja. Poznavanje najučinkovitejših načinov za prenos znanja $v$ prakso lahko močno pospeši hitrost učenja odraslih. Zato jih moramo postaviti $\mathrm{v}$ središče procesa učenja s prilagajanjem tečaja njihovim individualnim potrebam.

Rezultati raziskave so pomembni za učitelje, ki poučujejo odrasle, ter za pripravljavce programov za odrasle. Njeno jasno sporočilo je, da je treba odrasle bolj spodbujati k neformalnemu izobraževanju. Raziskava tudi potrjuje dognanja Alena Thomasa, ki je ugotovila, da ljudje ubirajo različne poti za doseganje želenega znanja, dodatna podpora andragoških ustanov k temu njihovemu neformalnemu izobraževanju pa jim pomaga, da ne zaidejo s poti in s tem po nepotrebnem ne izgubljajo dragocenega časa (Kranjc, 2000: 48). Prav tako bi bilo treba še pogosteje $v$ proces izobraževanja vključiti aktivne oblike učenja. V prihodnje bi bilo učinkovito organizirati neformalne skupine poleg tečaja, v katerih bi odrasle spodbujali $\mathrm{k}$ aktivnostim, kot so na primer: udeleževanje dogodkov, ki potekajo v tujem jeziku, ogled filmov $\mathrm{v}$ tujem jeziku, prepevanje glasbe $\mathrm{v}$ tujem jeziku, razpravljanje o tujejezičnih knjigah, klepet ali dopisovanje s tujci ... Prav tako bi bilo učinkovito $\mathrm{k}$ temu jih spodbujati $\mathrm{z}$ domačimi nalogami. Z njimi bi lahko spodbujali uporabo tujih strani na svetovnem spletu ali pa bi k uporabi tujega jezika spodbujali z obiskom restavracije, kjer z natakarjem ne smejo spregovoriti v slovenskem jeziku. Tudi to je poroštvo, da se bo pridobljeno znanje lahko uporabilo in prišlo do veljave $\mathrm{v}$ stiku $\mathrm{z}$ drugimi ljudmi in stvarnostjo (Kranjc, 2000: 50).

Tako bomo dosegli, da bo proces učenja še učinkovitejši, kar pomeni, da bomo dosegali boljše rezultate v krajšem času. Prav tako so dognanja pomembna za odrasle, ki so vpeti v oblike neformalnega izobraževanja, saj lahko s pridobljenim znanjem precej skrajšajo čas učenja in povečajo učinkovitost svojega izobraževanja. Raziskava potrjuje tudi spremembe $\mathrm{v}$ paradigmi izobraževanja v informacijski družbi, ki sta jih ugotovila že Beck (1996, v Kranjc, 2007) in Nezel (2000, v Kranjc, 2007). Tako potrjuje, da je uspešnejše fleksibilno neformalno izobraževanje, ki ga sestavljajo neposredne razmere: življenjske in delovne situacije. Nova paradigma izobraževanja posameznika ne omejuje s predpisanim številom ur ali metodami, temveč priznava vsako pot do znanja, ki je učinkovita.

\section{LITERATURA}

Beck, U. (1996). Risk society: towards a new modernity. London: Sage.

Bjornavold, J. (2000). Makin learning visible: identification, assesment and recognition of non-formal learning in Europe. European Centre for Development of Vocational Training. Luxembourg: Office Publications of the Europen Communities.

Colleta, N. J. (1996). »Formal, Nonformal, and Informal Education«. V: A. C. Tuijnman, International enyclopedia of adult education and training. Oxford, New York, Tokyo: Pergamon.

Devjak, T. (2007). »Vizija Centra za nadaljnje izobraževanje in usposabljanje: formalno, neformalno in priložnostno učenje v procesu vseživljenjskega 
učenja pedagoških delavcev«. V T. Devjak, in P. Zgaga (ur.), Prispevki k posodobitvi pedagoških študijskih programov II. Ljubljana: Pedagoška fakulteta. 119-137.

English, L. M. (2005). International Encyclopedia of Adult education. New York: Palgrave Macmillan.

Gornik, J. (2005). Delovno gradivo Društva mladinski ceh s partnerji Uradom za mladino RS. Ljubljana: Društvo mladinski ceh.

Jarvis, P. (1990). An international Dictionary of Adult and Continuing Education. London, New York: Routledge.

Kranjc, A. (2007). »Nove paradigme vseživljenjskega izobraževanja«. Andragoška spoznanja, Ljubljana, 13(4): 10-27.

Kranjc, A. (2000). »Spontano individualno izobraževanje: nekatera teoretična izhodišča «. Andragoška spoznanja, 6(3): 48-51.

Kranjc, A. (1996). »Kakšno znanje potrebuje sodobni človek«. Andragoška spoznanja, Ljubljana, 2(3): 5-10.

Knowles, M. (1972). The modern Practice of Adult Education. London: Association Press.

Muller, H. (1965). Teaching and learning in adult education. New York: Macmillan. 41-66.

Muršak, J. (2006). »Kaj storiti z učinki informalnega učenja«. Sodobna pedagogika, 57(3): 10-27.

Pevec Grm, S. (2006). Kurikul na nacionalni in šolski ravni v poklicnem in strokovnem izobraževanju: metodološki priročnik. Ljubljana: CPI, Center za poklicno izobraževanje.

Rečnik, F. (ur.). (2004). Pedagoško-andragoško usposabljanje: priročnik za usposabljanje izobraževalcev (mentorjev, inštruktorjev, trenerjev, ...). Ljubljana: Zavod Republike Slovenije za šolstvo.

Rogers, A. (2005). Non-formal education: flexibile schooling or participatory education? Boston (MA): Springer.

Zorko Mencin, D. (2003). »Kakovostno jezikovno izobraževanje v organizacijah «. Andragoška spoznanja, Ljubljana, 9(1): 71-78. 